\title{
THE STANDARD OF CARE REQUIRED OF CHILDREN
}

\author{
HARRY SHULMAN
}

It is undoubtedly true that the law of torts does not generally hold children to the exercise of the same degree of care and intelligence that it requires of adults. To do otherwise, would be to shut its eyes, ostrich-like, to the facts of life and to burden unduly the child's growth to majority. Similar concessions to immaturity are made in other branches of the law. The same realism, however, necessitates the recognition of the fact that at some age prior to twenty-one, and in some situations, a minor: is fully as competent as a person over twenty-one and should be held to the same standard of conduct. It is not the purpose of this paper to discover that age and those situations. Assuming that the adult standard is not to be applied, the problem is what standard, if any, is to be used. Again, it is not the purpose of this paper to discuss the legal presumptions that many jurisdictions apply to minors. Such fictitious presumptions can be justified only, if at all, on grounds of expediency and facility in the administration of trials. But, whether or not the law of the particular jurisdiction raises a conclusive presumption that infants under seven years are incapable of contributory negligence, and rebuttable presumptions that minors between seven and fourteen are not capable and minors over fourteen are capable of contributory negligence, ${ }^{1}$ still the question is raised: If the minor is capable of negligence, by what standard, if any, is his conduct to be measured?

There are very few cases in which the problem is raised in an issue of direct negligence for which the infant is sought to be held liable. ${ }^{2}$ Most of the cases discussing the problem are concerned with the child's alleged contributory negligence, or assumption of risk or some other disabling contributory fault. In many cases where the child's conduct is considered, the only issue relates to the negligence of the defendant, and the infant's conduct is important only in determining whether or not the de-

I See Birmingham \& A. R. R. v. Mattison, 166 Ala. 602, 52 So. 49 (1909); L. R. A. 1917 F 10, 42, annotation; Notes (1926) 5 TEx. L. REv. 447; (1925) 74 U. PA. L. REv. 79.

2 For a well considered discussion of the general tort liability of infants see Bohlen, Liability in Tort of Infants and Insane Persons (1924) 23 MrCH. L. REv. 9, reprinted in BoHLEN, Studies IN THE LAW OF TORTS (1926) 543. See also (1925) 3 N. Y. L. REv. 389. 
fendant discharged his duty of reasonable care under the circumstances. ${ }^{3}$

The standard of conduct to which an infant is to be held when his own liability is in question may properly be quite different from that to which he is to be held when he seeks to recover from an admittedly negligent defendant. ${ }^{*}$ It is apparent that different considerations may be involved in these several types of cases. There is a strong policy in favor of protecting children from losses attributable to their immaturity. It would be quite plausible, therefore, for a court to be more lenient toward children whose injuries are attributable, not only to their immaturity, but also to conceded tortious conduct on the part of the defendant, than toward children who are the sole responsible causes of injury to others. Yet the cases do not enter into niceties. The opinions are replete with loose language, sometimes altogether unnecessary, sometimes equivocal, sometimes incomplete, and sometimes even contradictory of statements in the very same opinion. A law review editor has recently concluded that, for the purpose of determining contributory negligence,

"the acts of a child are tested by the individual capacity of the child himself .... [The standard] is subjective, depending entirely upon the individual capacity of the child." 43

It will be shown that such statements are not entirely true. There is some objective standard even in the case of children.

There are cases in which it is said that the care required of children is that care which is ordinarily exercised under similar circumstances by children of the same age. ${ }^{5}$ But it is apparent

3 It is obvious that an actor is required to be more careful when his conduct is likely to endanger children than when it is likely to endanger only adults. In general, unless a defendant has reason to lmow otherwise, he is entitled to assume that persons and things will react as they are commonly supposed to react under the circumstances. Children do generally exercise a lesser caution for their own safety than do adults. Since this is common knowledge, a defendant is not only entitled to assume it, but he is charged with the knowledge of it, and must act with a view to it. In determining a defendant's negligence toward a child, it may, therefore, become important to ascertain whether or not the defendant should have forseen a particular kind of conduct on the part of the child.

4 This may be true in the case of adults as well as in the case of children. Accepting the doctrine of contributory negligence, it does not at all necessarily follow that the care used by $X$ to prevent injury to others, or his duty to perceive the possibility of, and provide against, injury to others is to be measured by the same standard as that employed to measure the care that $X$ used to prevent injury to himself or his duty to foresee, and provide against, injury to himself by an admittedly negligent person.

$4^{\mathrm{B}}$ See Note (1925) 74 U. PA. L. REv. 79, 80.

5 Ayers v. Ratshesky, 213 Mass. 589, 101 N. E. 78 (1913); Jacobs V. Koehler Sporting Goods Co., 208 N. Y. 416, 102 N. E. 519 (1913). It is apparent from the context of the opinions in these cases that age is not the 
that such statements are not intended to be complete and that age is not the only individualized quality even in those cases.

Judicial opinion is overwhelmingly to this effect. Thus: ....." the sounder doctrine seems to be that age is an important but not decisive factor....." "It is the capacity, not the age of an infant that is the criterion. ..." " "The average child of its own age is not the standard by which to measure its legal diligence ... ." " 8 "Age is of no significance except as a mark of capacity." 9 "Age is not the true test in such cases." 10 Most of the plethora of cases on this point, including many in the jurisdictions cited in note 5, individualize some other qualities in addition to age. In one case or another, the courts have named, in diverse combinations the following qualities which are to be individualized: age, ability, alertness, appreciation, capability, capacity, comprehension, discernment, discretion, development, education, experience, intelligence, judgment, knowledge, maturity, reason, sex, understanding."11 Age is included in all the combinations. Usually the combination consists of three qualities;

only quality to be individualized. It is to be noted, further, that in such cases as the above there is no evidence of a departure by the particular child from the intelligence common to children of his age. It is therofore presumed that it is a child of normal intelligence for its age. See infre note 20.

${ }^{6}$ See Berdos v. Tremont \& S. Mills, 209 Mass. 489, 494, 95 N. E. 876, 878 (1911).

7 See Fink v. Kansas C. S. Ry., 161 Mo. App. 314, 330, 143 S. W. 568, 573 (1912).

8 See Herrington v. Mayor \& Council of Macon, 125 Ga. 58, 60, 54 S. E. 71,72 (1906).

9 See Western \& A. R. R. v. Young, 81 Ga. 397, 416, 7 S. E. 912, 914 (1888).

10 See Trudell v. Grand Trunk Ry., 126 Mich. 73, 78, 85 N. W. 250, 252 (1901).

11 Garrison v. St. Louis, I. M. \& S. Ry., 92 Ark. 437, 123 S. W. 657 (1909) ; Linthicum v. Truitt, 2 Boyce 338, 80 Atl. 245 (Del. 1911); Baltimore \& O. S. W. Ry. v. Then, 159 Ill. 535, 42 N. E. 971 (1896); Seifort v. Schaible, 81 Kan. 323, 105 Pac. 529 (1909) ; Berdos v. Tremont \& S. Mills, supra note 6 ; Baker v. Flint \& P. M. R. R., 68 Mich. 90,35 N. W. 836 (1897) ; Mollica v. Michigan C. R. R., 170 Mich. 96, 135 N. W. 927 (1912); Solomon v. Public Serv. Ry., 87 N. J. L. 284, 92 Atl. 942 (1915) ; Ackerman v. Stacey, 157 App. Div. 835, 143 N. Y. Supp. 227 (4th Dept. 1013) ; CloveIand C. C. \& St. I. Ry. v. Grambo, 103 Ohio St. 471, 134 N. E. 648 (1921); Thomas v. Oregon Short Line, 47 Utah 394, 154 Pac. 777 (1916); Bentson v. Brown, 186 Wis. 629,203 N. W. 380 (1925); Ramirez v. Cheyenne, 34 Wyo. 67, 241 Pac. 710 (1925); see (1927) 2 WASH. L. REv. 204.

Of course, in so far as a court recognizes the conclusive presumption that children under a given age are incapable of contributory negligence, ago is, for children in that class, the sole standard and the only individualized quality. 
and the combination,-age, intelligence and experience is the most frequent one.12

If a child is unusually intelligent, or experienced, or well informed for one of his age, he is held to the exercise of greater caution than the ordinary child with the intelligence, experience, and knowledge common to that age. ${ }^{13}$ The quality of his conduct must be commensurate with his superiority. MIany of the cases found really go no further than that (though their language is general to the effect that the qualities of intelligence, experience and knowledge are always to be individualized in the case of children) ${ }^{14}$ An increase in the requirements on the ground of superiority does not, however, negative the existence of a minimum standard to which children must conform. Nor is the principle peculiar to cases of infants. If an adult has greater knowledge or experience than an ordinary person in his position would have, he is required to exercise that greater knowledge and experience. ${ }^{15}$ Instances of superiority are not important in determining a minimum standard.

Deficiencies of a particular individual are, however, of primary importance. On the whole, adults cannot defend imputations of negligence on the ground that in mental capacity, experience or knowledge they fall below the standard of the reasonable man. ${ }^{16}$ In the case of infants, on the contrary, deficiencies in mental capacity, experience or knowledge are to be considered in determining whether or not their conduct is negligent. Thus, the Delaware court has stated that the ordinary rule

"is to be modified according to the maturity and capacity of the infant, his ability to understand and appreciate the danger and his familiarity with all the surroundings ..... While a particular act committed by an infant of discerning age might clearly constitute contributory negligence, yet, if the same act should be committed by an infant of less discernment, it might not constitute contributory negligence." ${ }^{18}$

12 See cases collected in L. R. A. 1917 F 10-41, annotation.

13 MTarius v. Motor Delivery Co., 146 App. Div. 608, 131 N. Y. Supp. 357 (1st Dept. 1911); Grealish v. Brooklyn, Q. C. \& S. Ry., 130 App. Div. 238, 114 N. Y. Supp. 582 (2d Dept. 1909), aff'd 197 N. Y. 540, 91 N. E. 1114 (1910); Thomas v. Oregon Short Line, supra note 11 . Other cases cited in this paper also bear this out.

14 Thomas v. Oregon Short Line, supra note 11; Derringer v. Tatley, 34 N. D. 43,157 N. W. 811 (1916).

15 See Seavey, Negligence-Subjective or Objcctive (1927) 41 HArv. L. REv. 1, 17. But one is not held to his own valuation of interests and determination of social utility, or to his own judgment as to the propricty of conduct.

16 Professor Seavey, in the article cited supra note 15, admits this for the quality, intelligence, but qualifies it as to knowledge and experience.

17 See Linthicum v. Truitt, supra note 11, at 347; 80 Atl, at 249. 
So also, an Arkansas court held that where there was testimony to the effect that the plaintiff (16 years old) "was of inferior intelligence ... was not bright and did not have good understanding," the jury should have been instructed to consider the plaintiff's "intelligence" and "capacity." 18 Similar holdings are implicit in cases which refuse to make allowances for backwardness in the particular child on the ground that there was no evidence, or insuffcient evidence, of such backwardness..$^{10}$ The burden of raising the issue of, and proving, backwardness is on the child. If no claim of inferiority is made it is properly presumed that the child has the intelligence and experience common to children of its age. ${ }^{20}$

With all the above-named qualities individualized, even if they are not mutually exclusive, it is difficult to see what is left for standardization. The mere fact that there is such a great diversity of expression and so much periphrasis on this point is sufficient evidence to raise a strong doubt as to the existence of a standard.

Yet there seems to be some standardization. No court ever says that a child is to be held to the measure of care which the particular child in question ordinarily exercises. ${ }^{21}$ On the contrary, the courts always state the measure with some objectivity. The usual statement is that a child is held to the exercise of the degree of care which ordinary children of his age, intelligence and experience (or whatever combination is used) ordinarily exercise under similar circumstances. ${ }^{22}$ Sometimes it is the care which is reasonably to be expected of children of his age, ${ }^{23}$ experience and intelligence. Sometimes it is the care of the class of persons to which the injured belongs. ${ }^{24}$ Sometimes it is the

18 Garrison v. St. Louis, I. M. \& S. Ry., supra note 11.

19 North Hudson Co. Ry. v. Flanagan, 57 N. J. L. 696, 32 Atl. 216 (1895); Verdon v. Crescent Auto Co., 80 N. J. L. 199, 76 Atl. 346 (1910); Grube v. Baltimore, 132 Md. 355, 103 Atl. 948 (1918); Nicolosi v. Clark, 169 Cal. 746, 147 Pac. 971 (1915).

Such also is the import of the cases cited throughout this paper to the effect that the degree of care required of an infant is that reasonably to be expected from or ordinarily exercised by children of his age, intelligence and experience.

20 See Verdon v. Crescent Auto. Co., supra note 19. This may explain those cases cited supra note 5 which name only age as the individualized quality.

21 That would be the least requirement consistent with the application of the doctrine of contributory negligence, and it would be entirely individualized.

22 See almost any of the cases cited in this paper, particularly those supra note 11.

${ }^{23}$ Mollica v. Michigan C. R. R., supra note 11; Ramirez v. Cheyenne, supra note 11; Marius v. Motor Delivery Co., supra note 13.

24 Schoonover v. Baltimore \& O. R. R., 69 W. Va. 560, 73 S. E. 266 (1911). 
care of ordinary, ${ }^{25}$ prudent and careful children of his age, experience and so forth; or of the great mass of children of his age, and so forth. ${ }^{20}$ In the words of the Maine court, "The standard is the conduct of boys who are ordinarily careful." $=7$ Another Maine decision sets the standard as "that degree of care 'which ordinarily prudent children of their age and experience are accustomed to use under similar circumstances'. . . ." ${ }^{\text {"s }}$ A Missouri court has held it error to refuse an instruction which stated the standard as "a reasonably prudent and careful boy of similar age. ..." 29 A New York court has stated the standard to be the care of a "reasonably careful and cautious boy of that age. ..." ${ }^{30}$ A Delaware decision speaks of the standard as "that degree of care which children . . . of ordinary care and prudence are accustomed to exercise ...." ${ }^{12}$ Similarly an Arkansas opinion states it as "that care which one of his age, intelligence, and ordinary prudence would exercise ...." 32 Finally, a Maryland case ${ }^{33}$ quotes with approval a statement in a Massachusetts decision

"that children, as well as adults, should use the prudence and discretion which persons of their years ordinarily have, and that they cannot be permitted with impunity to indulge in conduct which they know, or ought to know, to be careless, because children are often reckless and mischievous." ${ }^{4}$

It cannot fairly be said that this persistence in expression is mere logomachy, or that such statements are euphemisms for expressions like "the care which this particular child ordinarily exercises." If a child has the capacity to appreciate danger and is sufficiently experienced to avoid it, but is regularly more reckless or daring than ordinary children of his age, intelligence and experience, he will be held to the standard of conduct established by such ordinary children rather than by his own usually reckless conduct. ${ }^{35}$ Evidence of particular trends towards reckless-

25 Bentson v. Brown, supra note 11; Day v. Cunningham, 125 IIe. 328, 133 Atl. 855 (1926); Sullivan v. Chauvenet, 186 S. W. 1090 (Mro. App. 1916).

${ }^{26}$ Quinn v. Ross Motor Car Co., 157 Wis. 543, 147 N. W. 1000 (1914).

${ }^{27}$ See Crosby v. Mraine C. R. R., 113 Mre 270, 274; 93 Atl. 744, 745 (1915).

${ }^{28}$ See Day v. Cunningham, supra note 25, at 332, 133 Atl. at 858.

29 See Sullivan v. Chauvenet, supra note 25 , at 1092.

30 See Ackerman v. Stacey, supra note 11, at 838, 143 N. Y. Supp. at 220.

31 See Linthicum v. Truitt, supra note 11, at 347, 80 Atl. at 249.

32 See Garrison v. St. Louis, I. MY. \& S. Ry., supra note 11, at 444, 123

S. W. at 661 .

33 See Havermale v. Houck, 122 MId. 82, 89, 89 Atl. 314, 316 (1913).

${ }^{34}$ See Collins v. South Boston R. R., 142 Mass. 301, 315, 7 N. E. 856, 860 (1886).

35 In addition to the cases cited supra notes 27 through 34 , see Bentson 
ness and impetuosity on the part of a particular child is not admissible on an issue of his contributory negligence. ${ }^{30}$

A similar restriction is evidenced in cases involving the liability of landowners to infant trespassers for injuries resulting from dangerous instrumentalities on their land. ${ }^{37}$ The doctrine of "attractive nuisance" is to be invoked for the protection of infants who cannot know or appreciate the danger, ${ }^{38}$ infants who do not "comprehend" the consequences "of meddling" with the instrumentality. "IS "If . . children of such age as to be ordinarily capable of discerning and avoiding danger are injured while trespassing upon the premises of another, they may be without remedy ...." ${ }^{40}$ In Brinkley Car Co. v. Cooper, ${ }^{41}$ the defendant left a pool of hot water on his land, and the plaintiff, six year's of age, stepped into it and was scalded. The court said: ${ }^{42}$

"If the pool of water was open ... and the boy had notice that it was hot, we think that the company could reasonably suppose that a boy of six years of age would not intentionally or carelessly put his foot into water known by him to be hot, and if he did so, and injury resulted, we do not think the company is responsible."

v. Brown, supra note 11; Cleveland, C. C. \& St. L. Ry. v. Grambo, supra note 11; Clerici v. Gennari, 132 Atl. 667 (N. J. 1926).

${ }^{36}$ Bridger v. Asheville \& S. R. R., 27 S. C. 456 , 3 S. E. 860 (1887); see Collins v. South Boston R. R., supra note 34. See also the following cases in which it was held that, as a matter of law, a child cannot recover whoro the evidence showed that he knew the danger and was intelligent enough to appreciate it: Moran v. Smith, 114 Me. 55, 95 Atl. 272 (1915); Schoonover v. Baltimore \&.O. R. R., supra note 24; Vorrath v. Burke, 63 N. J. L. 188, 42 Atl. 838 (1899) ; Austin v. Public Service Co., 299 Ill. 112, 132 N. E. 458 (1921); Zoltovski v. Gzella, 159 Mich. 620, 124 N. W. 527 (1910).

${ }^{37}$ For a full discussion of this problem see Smith, Liability of Landowners to Children Entering without Permission (1898) 11 HARv. L. REv. 349, reprinted in SELECTED ESSAYS ON THE LAW OF TORTS (1924) 357; Hudson, The Turntable Cases in the Federal Courts (1923) 36 HaRv. L. REv. 826, reprinted $i b i d .397$. For a reference to sources see also BoHLEN, Cases on Torts (2d ed. 1925). 366-386, particularly 383, n. 35. And seo Professor Bohlen's explanations in The Duty of a Landowner Towards Those Entering His Premises of Their Own Right (1921) 69 U. PA. L. REv. 340, 347-350, reprinted in BoHLEN, op. cit. supra note 2, at 190-193.

${ }^{38}$ See Chicago, B. \& Q. R. R. v. Krayenbuhl, $65 \mathrm{Neb} .889,900,91$ N. W. 880,882 (1902); McDermott v. Burke, 256 Ill. 401, 406, 100 N. E. 168 , 170 (1912).

${ }^{39}$ See George v. Los Angeles Ry., 126 Cal. 357, 364, 58 Pac. 819, 821 (1899).

\$0 See Tucker v. Draper, 62 Neb. 66, 73, 86 N. W. 917, 919 (1901), quoted with approval in Chicago, B. \& Q. R. R. v. Krayenbuhl, supra note 38, at $901,91 \mathrm{~N}$. W. at 882 .

110 Ark. 331, 67 S. W. 752 (1901).

42 Ibid. 336, 67 S. W. at 754. 
The leading case of Edington v. Burlington, C. R. \& N. Ry.,43 which introduced the "turntable doctrine" into Iowa, clearly points out that the doctrine can be invoked only for the protection of reasonably careful children, not for the protection of the reckless or daring. The court states: ${ }^{4}$

"... the hoodlums ... . find no immunity or protection in the law as we interpret it .... They know the difference between right and wrong and understand the meaning of trespass . . . They disregard property rights from mere love of mischief and take risks out of mere bravado, or in conscious defiance of moral and legal restraint. When a boy is thus injured, we may pity his folly, but justly say, as the law says, that, having intelligently assumed the risk, he ought not to recover damages."

The courts which recognize the doctrine of "attractive nuisance" will lift the defence of trespass only in favor of reasonably prudent children who cannot appreciate the fact that they are trespassing and acting wrongfully.45

Is there, then, any objective standard with which an infant's conduct must be compared? As to liability-creating conduct a conclusion cannot here be drawn. But as to contributory fault, at least, there is sufficient data for a conclusion. The mental capacity, the knowledge and experience of the particular child, are to be taken in consideration in each case. These qualities are individualized-subjective-but only for the purpose of determining whether or not the child was capable of perceiving the risk of injury to himself and of avoiding the danger. Beyond that, there is an objective standard. In determining whether or not his conduct was proper in view of his intelligence, knowledge and experience, his conduct is to be compared with that of the careful and prudent child of similar qualities. Just as in the case of adults, one of the qualities of the standard "reasonable man" is consistent carefulness or prudence, ${ }^{46}$ so in the case of infants, the element of prudence is standardized. A definition of the term will not be attempted. In this connection, at least, prudence does connote a certain selfishness-a proper regard for one's own safety. It includes more. It conveys an idea of proper evaluation of interests, of proper choice of conduct. At any rate, it is a conveniently vague term to admit of adjustment to particular situations in a field of law where certainty in advance is not all-important.

43116 Iowa 410, 90 N. W. 95 (1902).

44 Ibid. $436-7,90$ N. W. at 104.

45 Nicolosi v. Clark, supra note 19; Pennington v. Little Pirate Gas Co., 106 Kan. 569, 189 Pac. 137 (1920); Grube v. Baltimore, supra note 19.

46 See Seavey, op. cit. supra note 15, at 11, n. 11. 